\title{
MAY THE LOVE BE WITH YOU: FROM THE JOY OF LIFE TO THE TRANSCENDENCE OF EXISTENCE IN TAKAHATA ISAO'S ANIMATION WORKS
}

\author{
Maria GRAJDIAN ${ }^{1}$
}

\begin{abstract}
From Ponpoko: The Heisei Tanuki War (1994), through My Neighbours, the Yamadas (1999), and until The Tale of Princess Kaguya (2013), the animation movies directed by the reputed animation director Takahata Isao (1935-2018) and released by Studio Ghibli since mid1990s address the phenomenon of "life" as a meaningful endeavour towards attaining higher levels of human awareness. This occurs either by living in accordance with the flow of history, or by enjoying every moment as it comes, or, respectively, by delving into cosmic rhythms of imponderability: every single entity of existence delivers significance and comprehension, as displayed on multiple layers in the three animation works analyzed in this paper. Thus, in a phenomenological approach inspired by Julia Kristeva's monumental publication La Révolution du langage poétique (1974) which views cultural products as mirroring channels of repression (Verdrängung) and desire (Begehren), the analysis draws on an anthropological framework in which the researcher functions as a dynamic, self-reflexive interface mediating between the self-ness of the theoretical structure (here: life and the quest for its significance) and the other-ness of the representation medium (here: Japanese animated works).
\end{abstract}

Keywords: Japanese animation, Takahata Isao, joy of life, love, work-family balance

DOI: $10.24818 / \mathrm{SYN} / 2021 / 17 / 1.03$

\section{Introduction: in the quest for the meaning of life}

Recent debates in mass-media about the unexpected box-office success of what was supposed to be a plain origin-story of Batman's arch-enemy "the Joker" in the eponymous movie released at the beginning of October 2019 featuring Joaquin Phoenix in the lead-role, have brought into the spotlight important questions about the meaning of life and role of the individual within the society. Yet, already by early 1990s, Zygmunt Bauman (1991) had repeatedly warned about the emergence of what he referred to as "human waste", that is, those humans who are destined even before they are born to their total demise (e.g., refugees, unskilled emigrants and immigrants, orphans in war-zones or in poor areas/countries). Moreover, based on fundamental research of religious and philosophical trends throughout history,

\footnotetext{
${ }^{1}$ Maria Grajdian, Hiroshima University,grajdian@hiroshima-u.ac.jp
} 
thinkers from Friedrich Nietzsche to Jordan Peterson have been concluding that "life is suffering". While there seems to be no end and no solution, whatsoever ephemeral, to life's challenges and pains, artists and creators have been attempting since times immemorial to "feel" beyond the reality of the world and of its struggles, and to see whether there is a way to make sense out of its merciless hardships.

Takahata Isao (1935-2018) is one of such artists. A prominent Japanese animation director, he has been pursuing throughout his life pathways to represent life and its plurality of phenomena as a progressive endeavor to alleviate human suffering and despair. Out of his friendship with Miyazaki Hayao (born 1942), who has turned into one of the most successful animation directors in the history of the genre, he has grounded in 1986 the Studio Ghibli, one of the leading enterprises in the Japanese entertainment industry. ${ }^{2}$ The current paper focuses, in a phenomenological approach, on the meaning of life as a vibrant adventure, colorfully displayed in the last three animation works produced by Takahata Isao and released by Studio Ghibli since mid-1990s. This depiction of life as an unique enterprise to be pursued with passion and gratitude starts off with its orchestration as the "simple life" in Ponpoko: The Heisei Tanuki War (1994), lived in accordance with the passage of time, with the active acknowledgment of its joys and sorrows, ups and downs as well as the proactive quest for individual fulfilment within the broader community. It continues with a disenchanting display of the attitude "Live and let live!" as comprised in the expression tekitô-ni, brightly advocated in the lighthearted family comedy $M y$ Neighbours, the Yamadas (1999) - which reveals, though, darker undertones of sarcasm, when analyzed more closely: a subliminal feature that might possibly explain its failure at the domestic box-office. The climax of this evolution in the representation and explanation of life as a continuous adventure in the cosmic realm of eternity is found in the imponderability of existence from The Tale of Princess Kaguya (2013): the Japanese concept of mono no aware serves here as a bitter-sweet reminder that the ephemerality of human presence in the world is precisely that very element which renders it its very beauty, worth and fascination.

\footnotetext{
2 To the so-called "Ghibli Quartet" belong, together with Miyazaki Hayao and Takahata Isao, Suzuki Toshio (born 1948) and Hisaishi Joe (born 1950, real name Fujisawa Mamoru). The "founding quartet" included Takahata Isao, Miyazaki Hayao, Suzuki Toshio and Tokuma Yasuyoshi (1921-2000), with the last two serving as producer and manager, respectively. The composer Hisaishi Joe came later to join the Ghibli enterprise, after he was discovered by Takahata and Miyazaki when he presented the music proposal for the first official animation movie released by the newly-founded Studio Ghibli in 1986 Laputa: Castle in the Sky. Nowadays, one can talk of the Studio Ghibli in terms of an expanding "Ghibli corporation", with a Ghibli Museum founded in 2001 and located in Mitaka, Tokyo and a real-life replica of Satsuki \& Mei's House from the anime movie My Neighbour Totoro (1988) situated on the EXPO 2005's site in Nagakute, Aichi prefecture (both projected and built under the supervision of Miyazaki Gorô, Miyazaki Hayao's eldest son, born 1967) as well as a long-expected Ghibli theme park in Aichi prefecture, announced for opening in late 2020 or (more probably) early 2021 (Miyazaki, 2004: 55-72, 2012: 23-29).
} 
The phenomenological approach to products of popular culture as mirrors of repression (Verdrängung) and desire (Begehren) is explained in great detail in Julia Kristeva's La Révolution du langage poétique from 1974: it allows for a nuanced position of the anthropologist to function as a dynamic, self-reflexive interface mediating between the self-ness of the theoretical meaning (here: life and the quest for its significance) the and the other-ness of the analyzed medium (here: Japanese animated works). Furthermore, by placing the observer - in this case: the researcher - at the heart of the anthropological pursuit, it permeates beyond the strictness of the literature-based or interview-centered analysis, as the work of art as a phenomenon to be experienced, understood, questioned, transcended and, possibly, multiplied guides the "researching gaze" through the epistemological labyrinth.

Based on more than 20 years of empiric-phenomenological fieldwork in the multifaceted domain of mass-media and mass-mediated entertainment as well as its specific characteristics in the Japanese context, compounded by in-depth literature research on new media, cultural studies and cultural consumption with particular focus on Japan, this paper overcomes the typical focus on producers, consumers or their dialectical interaction, classically linked to the cyber-industry and digital/popular culture. Instead, I attempt to identify possible strategies to be employed towards a more loving future of the human existence, while taking into account the challenges humanity is facing currently, in a global perspective. The additional identity paradigms - in Japan as well as worldwide in the affluent postindustrialized, service-based nations - framing the "lonely individual" social phenomenon, of which "herbivore men" or feminized men and strong, self-assertive, but defeminized women (or "carnivore women") are typical examples, are regarded, succinctly, in historical-comparative perspective, while highlighting the complex existential dynamics in late-modern Japan and expanding from there in the wide world: the dialectical interplay of power, love and sexuality, on the one hand, and (cultural) consumption as well as state-driven reproduction politics, on the other hand, becomes obvious, ultimately. As to be shown in the Conclusion, there is a three-fold process of depicting the flow of life, both as an integral part of a greater cosmic plan and as an individual adventure.

\section{Ponpoko: The Heisei Tanuki War: "Live, and let live!"}

Tanuki (Nyctereutes procyonoides) - raccoon-like mammals - are the main characters in the animation movie Ponpoko: The Heisei Tanuki War 『平成狸合戦 ぽんぽこ』 released by Studio Ghibli in 1994 and directed by Takahata Isao. The animation movie presents the gradually vanishing homeland of the tanuki as a result of human intervention in its strive for progress and technological development, observed through the eyes of the affected protagonists, unable to defend themselves. Rather than being a fantastic narration with talking animals, Ponpoko: The Heisei 
Tanuki War is a huge fable executed with documentary precision (Takahata, 1999a: 68). However, in spite of intensive lobby promotion (Suzuki, 2018: 59), Ponpoko: The Tanuki Heisei War did not make it into the final stage to the Oscar nomination for Best Foreign Film in 1994.

Superficially speaking, Ponpoko: The Heisei Tanuki War transmits a common ecology-oriented message, supported by the deliberately deceptive music of Shang Shang Typhoon and its powerfully coloured allusions to Japanese folk songs: Major figures descending from famous Japanese folk tales, the mischievous tanuki, still massively present in the Japanese quotidian life, are employed by Takahata in his task to convey an emotional version of the ecological message so intimately attached to the Ghibli enterprise. The whole situation seems indeed inspired by the historical transformation of the Tama Hills in Western Tokyo in the first half of the 1970s, when new suburbs were built (Takahata, 2013: 72; see Sugimoto, 2013). Simultaneously with the powerful voice against the destruction of the natural habitat, as in Nausicäa from the Valley of the Winds (1984) or later in Princess Mononoke (1997), the happy, peaceful rurality from My Neighbour Totoro is evoked in the characters of the tanuki, who had come back into fashion and public awareness by mid-1990s in Japan.

On a deeper level, though, it becomes clear that Ponpoko: The Heisei Tanuki War is a hymn to life: life appears as the most valuable treasure to be possessed by a human being. It is probably no exaggeration to state that Ponpoko: The Heisei Tanuki War is for Takahata what Princess Mononoke would later be for Miyazaki (see further below): the artistic confrontation with that apparently favourite leisure activity of the modern human being consisting of constant attempts to kill the gods, to turn the sacred into the profane, to demystify the magic of life and of the world; in other words: bringing the netherworld into this world, out of pure fun (see Eagleton, 2003: 54, Ôtsuka, 2004: 53-56). The main problem, however, emerges when the modern human being shows its inability to replace this lost world brought to the surface with something new, equally mysterious and beautiful. Technology, science or longer life-span cannot fill in the gaps in the existence of late-modern social actors, caused by the loss, the disappearance and the disenchantment process of old folk tales and folk beliefs, fairy tales, myths and ghosts stories (see Lamarre, 2018: 52). They used to provide magic and miracles to a life otherwise dreary and bleak. In Ponpoko: The Heisei Tanuki War, Takahata navigates against this suffocating everyday life by delivering a soft touch of light and joy in his hymn to life - the life of humans and of nature with its animals and plants - as something extremely valuable.

An immense fable itself, Ponpoko: The Heisei Tanuki War talks about the destruction of the forest not only as the loss of the homes for those living there, but also as the destruction of what Hannah Arendt called "the common world" (quoted in Bauman, 2004: 22; see Arendt, 1976, Kristeva, 1989). Living beings are not 
separate entities, but they exist and co-exist within complex temporal and spatial as well as emotional networks. If their habitat is destroyed, an entire life-network is destroyed, at the same time, a small, vital, circular universe is ruined in the name of human progress and development. Nevertheless, it is worth going on living. Somehow. The tanuki learn this hard lesson despite their inner resistance; they subsequently adapt their ability to change shape to the new circumstances originating in their mythological ability to metamorphose - and take into account, pragmatically, the unavoidable victimization, followed by the mourning of the innocent victims (see Le Roux, 2009, Moon, 2002). The restoration of the original state of harmony is an endless process, and alongside this process both victories and defeats are faced with courage and dignity and accepted as such. This state of harmony which is yearned for by all living beings is never an existential circumstance in itself not to be addressed or challenged, but a process to be sought and attained within a long instructive and exhausting journey. This journey is commonly called "life".

The preoccupation with life as the most treasured possession to be acknowledged, protected and cherished infuses most animation works released by Studio Ghibli since 1994: Ponpoko: The Heisei Tanuki War (director: Takahata Isao) stands out as a pilot-project in the new direction, followed by the ground-breaking Princess Mononoke (director: Miyazaki Hayao) from 1997, which univocally, overwhelmingly conveys this message beneath the ecological propaganda. Like in Ponpoko: The Heisei Tanuki War earlier on, the superficial layer of ecological concern suffocates in Princess Mononoke the more profound - but nevertheless, vitally important - statement on the necessity to live one's life at its fullest while moving forward with the flow of history. Initially slightly humorously displayed in Ponpoko: The Heisei Tanuki War within the ethnocentric framework of the tanuki community's destruction by means of human progress and technology, this progressive vision of life turns gradually into a subtle reactive nostalgia throughout the movie, in the subtext of questioning human progress and its effects on other living beings, with clinical realism, but lacking cynicism and compounded by tender humor and warm humanism: two fundamental dimensions of the creative reaction to the realities of life and its set-backs while enjoying life to its full extent.

\section{My Neighbors, the Yamadas: "Live at your own pace!"}

It is crucial to learn to move with the flow of times and to experience life as an eternal celebration despite or just because of its difficulties and disappointments: the anime movie Hôhokekyo: My Neighbors, the Yamadas talks in a warm-hearted, gentle, and simultaneously serious manner of the importance of family as a balanced set of aspirations and concerns, on the one hand, and fulfillments and pleasures, on the other hand. It is a cheerful family comedy, displayed like a video comic strip, arguably in itself unusual, compared to most of other animation works released by 
Studio Ghibli, which are made in classic animation style. It was the first fully digital movie of the Studio Ghibli. Hôhokekyo: My Neighbors, the Yamadas received positive reviews, but still, it was a huge flop at the box-office - both domestic and international - and was followed by a long break in Takahata's creative activity until 2013, when his last animation movie The Tale of Princess Kaguya was delivered. This was not so much due to the topic it chooses to address, and much more due to the unusual characters and design style as well as due to the somewhat unorthodox treatment of the subject with its numerous ironic and self-ironic elements and surprising twists (Takahata, 2007: 12, Suzuki, 2008: 51, Odell and Le Blanc, 2009: 113). At the crossroads of the millennia, it seemed as if audiences, deeply troubled by a lack of ideological and aesthetic orientation, sought rather affirmative and straightforward works of art which could be taken as mental-emotional signposts, and less philosophical or critical inputs.

The plot of Hôhokekyo: My Neighbors, the Yamadas is based on the manga work of Ishii Hisaichi from the 1980s. It describes the everyday life of a (typical or not, depending on the perspective) Japanese family with their quotidian endeavors. Takashi is an average employee in an anonymous company, Matsuko is a ordinary, not exceptionally hardworking, housewife, Yamano Shige (Matsuko's mother) is a retired old-lady as to be found everywhere in Japan: obtrusive, annoying, know-itall, and yet somehow familiar with her fascination with larvae instead of the flowers that they eat away. Noboru (the elder son) is a student at a minor university and does not understand the meaning of continuous goal-oriented study, and Nonoko (the younger daughter) embodies the archetype of the spoiled, cynical girl:

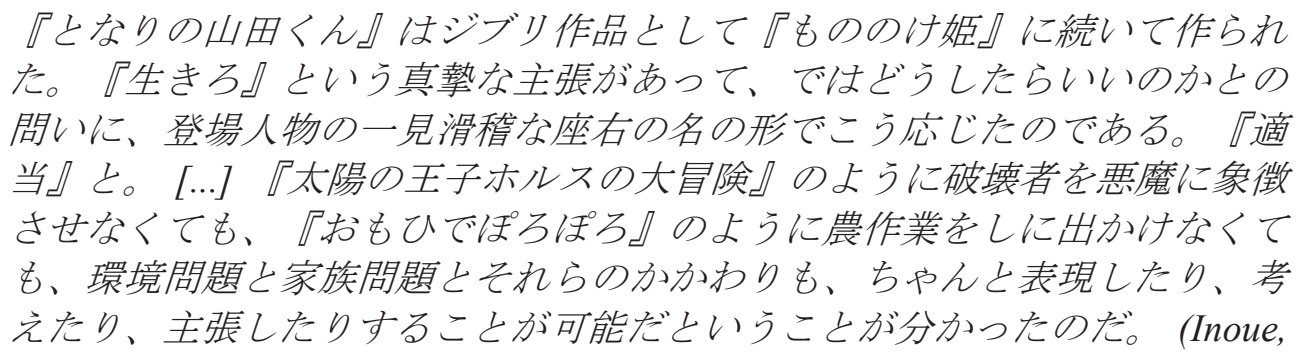
2004b:192)

[Hôhokekyo:] My Neighbours the Yamadas was produced as a Studio Ghibli animation work after Princess Mononoke. In this work [Princess Mononoke], there is the very seriously meant statement "Live!". To the question of how to do it best, the characters in [the animation movie] Hôhokekyo: My Neighbours, the Yamadas, obviously react with the funny, lovely verdict: "However you might like it! " [...] In doing so, [Takahata] clearly shows that it is indeed possible to openly address the problems plaguing the environment and the family as well as the connections between them, to reflect upon those issues and to express various opinions, without demonizing the perpetrators as in [the animation movie] The Prince of Sun: Horus' 
Great Adventure [1968] or to return to the fields and the physical work [implied by living in the countryside] as in [the animation movie] Memories like Raindrops [1991]. [my own translation]

As in every work by Takahata, this animation movie possesses a certain nostalgia and a particular human sensitivity beyond the precise art of representation. During the 144 minutes, with warm humor and empathetic irony, we accompany the Yamada family during various aspects of its everyday life, from domestic disagreements to work-related issues, in their narrative specificity (Takahata, 2009: 31; see Napier, 2005). The audience begins soon either to identify with the apparently crazy, but in fact amazingly universal family, or at least to love and admire them in their natural affection and down-to-earth approach to everything.

At the other end of the "lost 1990s", the profound disenchantment of the decade which had started for Takahata Isao with Memories like Raindrops (1991) and its bright, calm hopefulness, finds an inverse expression in Hôhokekyo: My Neighbours, the Yamadas: displayed in an unconventional, innovative drawing style and composed of several episodes describing the quotidian life of an average Japanese family in a humorous tone, it creates the emotional space for the audiences to increasingly identify with the Yamada members and their quotidian struggles, dreams, fears, misunderstandings and (small) victories (Thomas, 2012: 41; see Wells, 1998, Saito and Tsutsui, 2019). As often with the animation works directed by Takahata, Hôhokekyo: My Neighbours the Yamadas is a discrete masterpiece and a huge flop at the box-office, remaining nonetheless a powerful reminder that true happiness resides in the small things, occurring on an everyday basis, and which we tend to pass by without taking notice of them: the green grass on the side of the pedestrian way, the smiling "Good morning!" of an anonymous passerby, the ephemeral rainbow after the rain, the butterflies playing at the beginning of the summer, the twinkling stars in the night-sky. The soft, warm humanism which supports the directing act of this unobtrusive family-comedy is the foundation of that mental state in which we learn to accept those around us in their fundamental alterity, as Emmanuel Lévinas famously put it decades ago (Lévinas, 1961: 32), and to love them despite - or precisely because - their flaws and inconsistencies.

\section{The Tale of Princess Kaguya: "Grateful to have been born into this world - and to have lived so far."}

From the other end of history, The Tale of Princess Kaguya draws its story-line from the oldest-known Japanese folk-tale named The Tale of the Bamboo-Cutter (Taketori Monogatari): regarded as the most ancient Japanese prose narrative with roots back into the Japanese folklore of the $10^{\text {th }}$ century, although the first officially recognized manuscript dates from 1592 (Keene, 1993: 122, Takahata, 1999b: 121-198), it is the life-history of a mysterious little girl found in a bamboo tree in a forest by an old 
bamboo-cutter; together with his wife, the childless couple decides to raise the babygirl in their rural home. There is nothing new in this narrative construction, which metamorphoses under Takahata's directorial vision into a timelessly devastating parable on the shallowness of earthly possessions and on the transcendental power of love. Superficially speaking, The Tale of Princess Kaguya is the life trajectory of a reluctant young girl painfully longing to return to the forests and the hillsides of her childhood - which becomes in Takahata's transmutation of the millennia-old question on the right pathway to follow, a meditation on life's heartbreaking ephemerality. Arguably rooted in Uchida Tomu's [1898-1970] abandoned Tôei Animation project from the 1960s (Suzuki 2018: 118), the animation movie emerged slowly, over roughly a strenuous decade of quests, failed attempts and inconvenient timings, and the end-result appears as a subtly unfinished-looking freehand, subliminally suggesting the animators' efforts in symbolically chasing after the princess in person, fiercely doing their best to grasp each moment in its essential uniqueness as it flew away. More importantly, Takahata employs classical ancient Japan as the historical background, which allows him to deliver an uncanny register blending humanist social-realism with a clear-eyed spiritual perspective while pushing the limitations and challenges of the animated medium to its very expressive boundaries. Landscapes are focused at their center and fade towards the edges of the frames. At moments of heightened emotion - one of such extremely intensive scenes being the princess' frenzied escape from her coming-of-age celebrations, one of greatest-ever sequences in the history of animation - characters seem to literally fall apart into whirlwinds of disparate lines and shapes of water-colour, charcoal and pastel-nuances. The visual impact is similar to that of a surrealistic painting-inmotion, reminiscent of the recurrent simplicity of an old painted hand-scroll (emakimono) coming back to life and haunting the present.

At its very core, The Tale of Princess Kaguya is an animated Bildungsroman (novel of formation in Western literature) which focuses on two elements in the construction process of individual identity: the profound crisis which incites the subsequent conscious commitment towards oneself, flaws and dreams included, with the necessary temporally limited alienation from external compulsions. While overcoming individual layers of self-questioning, self-loathing and self-recovery is important, the completion of this process of identity construction is equally crucial: in The Tale of Princess Kaguya, there is a specific dystopian undertone visible in the dismantlement of family ideals and the inevitable loss of extended community, even more highlighted by the ending, respectively, in the sudden leap into magical fantasy in the love scene at the climax of the movie. To be sure, the adultery scene between Princess Kaguya and her childhood friend Sutemaru is unique in Studio Ghibli's strict moral guidelines (Grajdian, 2010: 21-23; see Fuller 2007), but there is, at the same time, a deep wisdom in the powerful display of the physical transgression of rules, regulations, interdictions, a deep sadness, and an even deeper despair. Potential clues to this scene are found in the animation movie's tag-line - "a princess' crime 
and punishment" - which reveals Takahata's intention to explore the possible "crime" Princess Kaguya might have committed (an issue which the original story and other re-makes are silent on) within an exploratory pursuit which cleverly avoids the plotline itself and refers almost exclusively to his heroine's emotional-spiritual journey of initiation as well as the way it ends (see Keene, 1993: 77, Bary, 1995: 58, Aida, 1994: 39). The love scene of forbidden desire is the ideological climax of the animation movie which hauntingly, wrenchingly, evokes the concept of mono no aware and its literal translation as the "pathos of things": apparently a major stone in the foundation of Japanese aesthetics and existential philosophy since time immemorial, mono no aware does not fall under any strict definition, but The Tale of Princess Kaguya sparklingly illuminates it with images of life as being the loveliest in its fierce transience, of farewells - even the unspoken ones - in their terrible finality. Unlike the other 2013-blockbuster of feminine experimentation Frozen (released by Walt Disney Pictures and a major box-office hit worldwide Japan included), which had scored points mainly for its originality in the tender acuity in observing the relationship between the two sisters, Elsa and Anna, The Tale of Princess Kaguya proclaims individual fulfillment and a clear sense of self as emerging from "love".

In Takahata's vision of femininity, love is an "invented emotion" intensely bargained by proto-feminists: in their quest for a functional definition of femininity, of its features, its challenges, its necessities as well as its ideals and perils, such intellectuals as Simone de Beauvoir or Julia Kristeva contemplated femininity as a transfer site of significance, which leads to socio-cultural affiliation as a consequence of conscious choices on the basis of everyday events and cumulated life experience. More than mental clarity, emotional ambivalence becomes the impetus to intellectual activism transcending time and space (see Bourdieu, 1979: 128-137, Morley and Robins, 1995: 79-81). In doing so, Takahata moves away from the genre of the Bildungsroman - animated or not - as a repertoire of classical education and formation and accedes in The Tale of Princess Kaguya (as Frozen's directors Chris Buck and Jennifer Lee had done in their own ways) aestheticideological spaces which allow the overcoming of loss and fear by means of imagining the mature individual, embedded in historical reality, capable of responsible, self-aware participation. Driven by love, for oneself and for others, the responsible, self-aware citizen lives in the moment and respects life as the most precious object ever: an unstable symbol of the "feminine self" of late modernity, Princess Kaguya sees her role as part of a greater whole as well as her potential to emerge from within this very greater whole as a messenger of gratitude and forgiveness; nevertheless, she still has to obey the flow of destiny and to move away, while embracing the power of remembrance. 
In Ponpoko: The Heisei Tanuki War and Hôhokekyo: My Neighbors, the Yamadas, Takahata Isao had been orchestrating the stress-ratio between community and the individual comprised within that very community. In The Tale of Princess Kaguya, on the other hand, Takahata Isao openly questions the importance of community and aligns himself with modern, arguably rigurous, mindsets of liberation and empowerment in the process of attaining fulfillment and happiness - and attempts to locate the position of the individual within the larger framework of the society, the nation or the world at large. In themselves, fundamental mental tools in fashioning a sense of self, regardless whether it is conceptualized as a fixed structure or a dynamic development, both liberation and empowerment appear equally fundamental in self's relation and correlation to an "other" in his/her "radical alterity" (Lévinas, 1961), eventually leading to the transcendence of the self through an "other" (Giddens, 2020: 121, Inoue, 2004a: 143). In Takahata's vision, a liberated, empowered human being comprehends responsibilities in the same light as rights, that is, an existence of freedom and self-determination in the service of truth, compounded by a keen awareness of togetherness with "others" in imperfection, in fragility and vulnerability, so that an authentic world of belonging and acceptance can emerge.

In this reading, The Tale of Princess Kaguya conveys a reminder of the role of popular media in times of ubiquitous coolness and cutification of culture, to turn towards local myths and legends beyond the nostalgic consumerism and to seek for classical worldviews promoting sustainable life strategies. The simultaneous intellectualization of products of popular media outlets encompasses, maybe notsurprisingly, the rather conservative message that love, happiness and existential fulfillment might be more than ever individual choices in late modernity (see Butler, 1993: 117, Köhn, 2005: 173, Castells, 1997: 285-288). In this bold statement of ideologically loaded creativity, Princess Kaguya finds the credibility necessary to transform her from a mere animated character into a symbol of self-aware and possibly self-sufficient femininity: she rises above impossible standards of beauty, success and likeability and decides that her destiny is her own business, emerging from the very choices that she is making every single moment. A bitter pill to swallow for the entitled shinjinrui-generation of the 1960s and 1970s, to be sure, but optimist and action-inducing in its realism: in Princess Kaguya's determination that her fulfillment does not mean direct connection with a man, but solely results from the pursuit of her own pathway in life, and in her commitment to stay true to herself, late-modern social actors find solace and inspiration. Love is something to give generously, to oneself and to others, by no means something to expect or request from others. It is a mindful choice occurring every day, like happiness and the soft, warm sense of belonging. In Princess Kaguya's attitude towards life, there is the ineffable promise of a better world to arise from solitude and acceptance, replacing the confusion and chaos of the present, while quietly celebrating the human being and humanity in their explosive, spectacular diversity and limitless potential. 


\section{Conclusion: transcending suffering and ephemerality through existential joy}

Within the complex micro-cosmos of human lives brought into existence by Takahata's vision of an animation which not only represents the multilayered dimensions of reality, but also enhances it with hopes and alternatives mostly impossible in the everyday realm, a poignant gradation becomes visible during the creation process spanning almost two decades. There are three levels on which this gradation takes place, encompassing the beginning of a more-realistic-than-life representation of existence and its struggles as well as its joys, through a powerful simplification of lines, shapes and nuances, so that the human essence turns strikingly obvious, and culminating into an almost ineffable effacing of colors and contours, so that characters and storylines metamorphose into pretexts for a sensitive idealization of emotions, thoughts, gestures, actions and attitudes.

On a first level, Ponpoko: The Heisei Tanuki War as a celebratory work of art takes over the positive tones from The Wings of Honneamise and announces later masterpieces such as Spirited Away (Sen to Chihiro no kamikakushi, literally: Chihiro's sudden disappearance, 2001, director: Miyazaki Hayao, music: Hisaishi Joe), which talk about the need for dreams and gods in a crumbling world as the epic representation of a little girl searching for her true self and working hard to rescue her parents (Murase, 2004: 65). Ponpoko: The Heisei Tanuki War is a story of hope and defeat; it is also a story on the continuity of life and the value of community as being more than solely the sum of its members. Ultimately, it is the story of belonging and renewal beyond the transgression of history.

On a second level, the quiet, cheerful climax represented by Hôhokekyo: My Neighbours, the Yamadas encapsulates the soft message that humans go on dreaming of heroic missions to save the world from extinction and from the horrid boredom of an never-changing quotidian life (Nakamura, 1999: 29, Takahata, 1999a: 21), even though this exists solely in their imagination. Herein, not only the Japanese youth in post-recession Japan, but also Western youths in super-saturated societies can find models for new, fresh life projects. Family values and inter-generational interdependence, social conformism and personal fulfillment, simple gestures of affection in the life of average social actors provide individual solutions to general constraints and obligations, and reveal new horizons of unlimited potential and hopeful infinity. Taking this vision as a foundation for his works, Takahata designs his characters in the spirit of acceptance, with worries, dreams, contradictions, optimistically delivering them to the world at large via the generous medium of the (Japanese) animation: despite difficulties, both family and life are to be enjoyed in their absolute fullness and uniqueness. It is an almost intrusive invitation to celebrate those around us as beautiful, lovely participants in the greater game of life, leading, 
inevitably, towards an empowerment of the individual human being - be it in discrete family sagas or on the broader stage of social events.

On a third level, The Tale of Princess Kaguya comes as a refreshing counter-proposal which profoundly touches the problematic of reviewing those tales which used to represent humanity as a place of warmth, softness and acceptance - more often than not, heavily re-written by the intellectual collectors of folkloric wisdom and recalibrated to be released from the dark tones of survival strategies to suit the progressive visions of modern times. Takahata's version of reinventing the past as a repository of knowledge and inspiration draws its narrative energy from the necessity to replace contemporary models of success - measured in terms of materialist accomplishments in accordance with socio-economic pressures - with the more sustainable paradigm of contentment and individual choices - which brutally clashes against educational programs and prevailing role-models imposed by Macchiavelic mainstream media (Bauman, 2003: 25, Luhmann, 1996: 32; see Fuller, 2012: 44-48). Simultaneous with the transmutation of "male" and "female" from their biological determination into the discursive formation, the intrinsic nature of "masculinity" and "femininity" is intensively re-negotiated on the basis of permanently shifting patterns and criteria, so that success, progress, popularity turn increasingly into impenetrable areas of hedonist lifestyles. The Tale of Princess Kaguya breaks into this chaos with powerful rays of order and coherence: putting aside the audiences' need for superficial optimism and infantile validation, Takahata Isao pushes in his directorial design beyond the plain message of "the charming prince will come one day" and/or its expanded version "nevertheless, you are perfectly fine without him - you can live happily ever after without him": his proposal advocates hard-work and discipline, compounded by faith and humility, respect and loyalty, with lifegoals to be established both pragmatically and courageously. In the steady nurturing of those life-goals, victories are cherished and failures serve as important lessons along the way. This alternative existential philosophy stands in stark contrast to present-day delusional charms of a worldview displaying the cultural consumption of pre-fabricated emotions and instant gratification as tactics to thrive, individually and socially. It focuses instead on disclosing the irresistible beauty of human life as an infinite project of love, acceptance and compassion.

This gradual process of celebrating life in its multitude of joys and sorrows, thus overcoming its fundamental suffering and the accompanying nihilism, stays in stark contrast to the emergence of a deeply disturbing social phenomenon in present-day Japan: the emergence and proliferation of the so-called "human waste" and its haunting occurrence on the background of a media-reinforced atmosphere of economic insecurity and political volatility. In his seminal study from 2004, Zygmunt Bauman referred to "human waste" (refugees, immigrants, asylum seekers, etc.) as an inevitable product of historical development, as modernization reaches even the most distant localities of the planet. However, as Takahata gently suggests 
in all his animation works, since his debut-work The Prince of Sun: Horus' Great Adventure from 1968, "human waste" has been present in all human communities and societies since times immemorial. The only difference to its current appearance with its typical features - the rejection of the real world and the simultaneous retreat into the virtual space with its three major layers (social network sites/apps, video games, online pornography) - is less the high degree of labor precarity, but rather the fact that it affects (almost) exclusively the male population. While it is arguably a direct consequence of neo-liberal strategies employed by political establishments all-over the world to re-invigorate local economies and reiterate narratives of sociocultural cohesion and resilience, a collateral effect of the widening gap between the technocratically driven visions and decisions of current governments and the passive-aggressive attitude of the general population (and most prominently, the male demographics) is to simply do "as if" they follow the instructions "from above" while quietly keeping on ignoring them.

In his far-sighted vision of a humanity which is both able and willing to sacrifice instant gratification for the sake of long-term benefits, provided that the necessary foundation of a trustworthy, functional social contract is established, Takahata Isao included the necessity of education and personal growth as core parts of the modernity project. Like many of his generational fellows, he understood that concepts like "freedom" and "equality" bear little meaning when broken apart from "responsibility" - that is, individual responsibility as the vital premise for any democratic, enlightened group of humans. Desperate times might call for desperate measures; but before desperate times kick in, it helps to foresee their appearance by means of integrity and hard-work. The joy of life as preached and orchestrated in terms of animation in Takahata's works is a juxtaposition of discipline and insight, harmoniously compounded by straightforwardness and unconditional relaxation when appropriate, as well as the prevalent request for an almighty sense of love and of self-love. In breaking through the glass-wall of public expectations for unlimited hedonism as the answer to current uncertainties, Takahata Isao brought forth works of art which both challenge the perception of the human being as slave to a destiny it cannot change and exposes a life project with the individual in its purest form - as a "responsible individual" - at its center. Long before social analysts have brought back into media-spotlight "individual responsibility" as the key-feature of any functional, healthy over-individual grouping of humans, Takahata Isao delivered it as animation narratives of hope, loneliness and remembrance.

\section{References and bibliography}

Aida, Y. 1994. Nihonjin no wasuremono [The things the Japanese have forgotten], Tokyo: PHP Kenkyûjo.

Arendt, H. 1976. The Origins of Totalitarianism, London: Harcourt Brace Jovanovich Publishers. 
Bary, T. 1995. "The Vocabulary of Japanese Aesthetics I, II, III", in Hume, N.G. (ed.): Japanese Aesthetics and Culture - A Reader, Albany: State University of New York Press: 43-76.

Bauman, Z. 1991. Modernity and Ambivalence, Cambridge: Polity Press.

Bauman, Z. 2003. Liquid Love - On the Frailty of Human Bonds, Cambridge: Polity Press.

Bauman, Z. 2004. Wasted Lives - Modernity and its Outcasts, Cambridge/ Oxford: Polity Press.

Bourdieu, P. 1979. La Distinction - critique sociale du jugement, Paris: Éditions de Minuit.

Butler, J. 1993. Bodies that Matter - On the discursive limits of "sex", London/ New York: Routledge.

Castells, M. 1997. The Information Age: Economy, Society and Culture II: The Power of Identity, Oxford/ Malden (Mass.): Blackwell Publishers.

Eagleton, T. 2003. After Theory, New York: Basic Books.

Fuller, M. 2007. Media Ecologies - Materialist Energies in Art and Technoculture, Cambridge (Mass.)/London: MIT Press.

Fuller, M. and A. Goffey. 2012. Evil Media, Cambridge (Mass.)/ London: MIT Press.

Giddens, A. 2020. The Third Way - The Renewal of Social Democracy, Oxford: Polity Press.

Grajdian, M. 2010. Takahata Isao, Frankfurt-am-Main: Peter Lang Press.

Inoue, S. 2004a. Anime-jenerêshon: Yamato kara Gandamu he no anime bunkaron [The Anime Generation: Anime Cultural Studies from Yamato until Gundam], Tokyo: Shakai-Hihan-sha.

Inoue, S. 2004b. Miyazaki Hayao: Eizô to shisô no renkinjutsu [Miyazaki Hayao: The Alchemist of Images and Ideas], Tokyo: Shakai-Hihan-sha.

Keene, D. 1993. Seeds in the Heart, New York: Henry Holt.

Köhn, S. 2005. Traditionen visuellen Erzählens in Japan - Eine paradigmatische Untersuchung der Entwicklungslinien vom Faltschirmbild zum narrativen Manga, Wiesbaden: Harrassowitz Press.

Kristeva, J. 1974. La Révolution du langage poétique, Paris: Éditions du Seuil.

Kristeva, J. 1989. Étrangers à nous-mêmes, Paris: Éditions Fayard.

Lamarre, T. 2018. The Anime Ecology - A Genealogy of Television, Animation, and Game Media, Minneapolis/London: University of Minnesota Press.

Le Roux, S. 2009. Isao Takahata: Cinéaste en animation - Modernité du dessin animé de l'insolite, Paris: L'Harmattan.

Lévinas, E. 1961. Totalité et infini, La Haye: Nijhoff.

Luhmann, N. 1996. Die Realität der Medien, Opladen: Westdeutscher Press.

Miyazaki G. 2004. Zôho kaitei ban: Mitaka no mori Jiburi Bijutsukan zuroku [Enhanced and Expanded Edition: The Catalogue of Ghibli-Museum in Mitaka Forest], Tokyo: Tokuma Memorial Association for Animation Culture. 
Miyazaki G. 2012. Satsuki to Mei no ie no tsukurikata [The Construction Method of Satsuki \& Mei’s House], Tokyo: Ghibli Studio/Tokuma Press.

Moon, O. 2002. "The countryside reinvented for urban tourists - Rural transformation in the Japanese 'mura-okoshi' movement", in Hendry, J. and M. Raveri (eds.), Japan at Play: The ludic and the logic of power, London/ New York: Routledge: 228-244.

Morley, D. and K. Robins. 1995. Spaces of Identity: Global Media, Electronic Landscapes and Cultural Boundaries, London/ New York: Routledge.

Murase, M. 2004. Miyazaki Hayao no fukami he [On Miyazaki Hayao’s Depth], Tokyo: Heibonsha.

Nakamura, K. 1999. "Mononoke Hime” kara "Hôhokekyo: Tonari no Yamada-kun" he [From "Princess Mononoke" to "Hôhokekyo: My Neighbours, the Yamadas"], Tokyo: Tokuma Shoten/Studio Ghibli.

Napier, S. 2005. Anime from Akira to Howl's Moving Castle: Experiencing Contemporary Japanese Animation, New York: Palgrave.

Odell, C. and M. Le Blanc. 2009. Studio Ghibli: The Films of Hayao Miyazaki and Isao Takahata, Harpenden: Kamera Books.

Ôtsuka, E. 2004. 'Dentô' to ha nani ka? [What is 'tradition'?], Tokyo: Chikuma Shinsho.

Saitô, C. and R. Tsutsui. 2019. Takahata Isao: A Legend in Japanese Animation, Tokyo: NHK Promotions Inc./ The National Museum of Modern Art.

Sugimoto. Y. 2013. An Introduction to Japanese Society, Cambridge/New York/Melbourne: Cambridge University Press.

Suzuki, A. 2008. Animating the Chaos: Contemporary Japanese Anime, Cinema and Postmodernity, Ann Arbor: ProQuest.

Suzuki, T. 2018. Mixing work with pleasure: My life at Studio Ghibli, translated by Roger Spears, Tokyo: Japan Library.

Takahata, I. 1999a. Eiga wo tsukurinagara kangaeta koto II: 1991-1999 [What I was thinking while creating movies II: 1991-1999], Tokyo: Tokuma Shoten.

Takahata, I. 1999b. Jûniseiki no animêshon: Kokuhô emakimono ni miru eigateki, animeteki naru mono [Cartoons of the 12th century: Movie- and anime-like things which one sees in the picture scrolls regarded as national treasures], Tokyo: Tokuma Shoten/Studio Ghibli.

Takahata, I. 2007. Manga-eiga no kokorozashi: "Yabunirami no bôkun" to "Ô to tori" [Notes on the cartoons "La Bergère et le ramoneur" and "Le Roi et l'oiseau"], Tokyo: Iwanami Shoten.

Takahata, I. 2009. Ichimai no e kara: Nihon-hen, Kaigai-hen [Starting from onesheet-pictures: Japan volume, oversea volume], Tokyo: Iwanami Shoten.

Takahata, I. 2013. "Taiyô no ôji: Horusu no daiboken” kara "Kaguya-hime no monigatari” made [From "The Prince of Sun: Horus' Great Adventure" until "The Tale of Princess Kaguya"], Tokyo: Kinema-Junpôsha.

Thomas, J. 2012. Drawing on Tradition: Manga, Anime and Religion in Contemporary Japan, Hawaii: University of Hawaii Press.

Wells, P. 1998. Understanding Animation, London/New York: Routledge Press. 


\section{The author}

Maria Grajdian is an Associate Professor of Media Studies \& Aesthetics of Subculture(s)/Popular Culture(s) at Hiroshima University, Graduate School of Integrated Arts and Sciences (Hiroshima/Japan). She holds a Ph.D. in musicology from Hanover University of Media, Music and Drama, Germany. Her research and teaching focus on Japanese contemporary culture, history of knowledge and the dynamics of identity in late modernity. Recent publications include a number of research articles in academic journals as well as books, e.g., After Identity: Three Essays on the Musicality of Life and Cyberspaces of Loneliness: Love, Masculinity, Japan (both 2019, ProUniversitaria Press). 